OPEN ACCESS

Edited by: Simone Sehnem, University of West of Santa Catarina, Brazi

Reviewed by: Andrea Urbinati, University Carlo Cattaneo, Italy Arvind Upadhyay, University of Brighton United Kingdom

*Correspondence: Cristina M. Ostermann cris.ostermann@gmail.com

Specialty section

This article was submitted to Circular Economy, a section of the journal

Frontiers in Sustainability

Received: 29 August 2021 Accepted: 06 October 2021 Published: 29 October 2021

Citation:

Ostermann CM, Nascimento LS and Zen AC (2021) Business Model Innovation for Circular Economy in Fashion Industry: A Startups Perspective. Front. Sustain. 2:766614. doi: 10.3389/frsus.2021.766614

\section{Business Model Innovation for Circular Economy in Fashion Industry: A Startups' Perspective}

\author{
Cristina M. Ostermann*, Leandro da Silva Nascimento and Aurora Carneiro Zen \\ School of Management, Federal University of Rio Grande do Sul, Porto Alegre, Brazil
}

Circular Economy (CE) has emerged as a potential strategy for developing business practices based on sustainability concerns, especially in the fashion industry, which presents high environmental and social impacts. Startups are responsible for introducing innovations in business conduction toward CE. As a current theme, research on Business Model Innovation for Circular Economy (BMI4CE) has increased. However, empirical research in the fashion industry and startups is still scarce. This paper aimed to identify the key elements of startups' BMI4CEs, using the fashion industry as the context of the study. We conducted an exploratory and descriptive multiple case study composed of ten early-stage fashion startups from Europe, North America, and Asia. The findings suggest that environmental and economic sustainability dimensions receive priority in the analyzed BMI4CEs. On business type, we found differences between productbased and service-based Business Models (BMs). The Business Models Innovations (BMls) were based mainly on CE principles of closed-loop and reducing material use and consumption. BMs focus on CE strategies of product reuse and extend resource time by lowering consumption and material use. Findings also demonstrate the role of emerging and digital technologies (e.g., blockchain and artificial intelligence) for BMI4CEs effectiveness. We developed five propositions and a theoretical framework from a triple bottom line perspective. This research highlights new theoretical perspectives under an investigation area still little explored in the literature. Results enable fashion startup managers to understand better the functioning of BMI4CEs and the critical elements needed for their effectiveness.

\footnotetext{
Keywords: circular economy, business model innovation (BMI), circular business model (CBM), startup, circular-
} born, fashion industry

\section{INTRODUCTION}

Circular Economy (EC) has emerged as a strategy for achieving sustainability (Korhonen et al., 2018). From a restorative perspective, CE seeks to change the systemic logic of economic activity. It proposes that companies no longer operate in a linear production and consumption system, but in an economy based on circularity (Prieto-Sandoval et al., 2018), in which aspects of sustainability are essential for shaping the performance of companies and the relationships among these and other social and economic agents.

In this context, companies need to rethink their business models (BMs), aligning them with the circularity precepts. As BM corresponds to the ways companies adopt to improve market performance based on new ideas and technologies (Chesbrough, 2010; Teece, 2010), CE 
adoption takes shape through the business model innovation (BMI). Innovation is responsible for disrupting both the way companies operate and the way consumers act and react. It has the potential to spearhead the necessary changes in companies' actions toward systemic environmental preservation, generating positive impacts in the economic sphere and sharing superior ecological, social, and economic value among spheres (PrietoSandoval et al., 2018). Thus, the Business Model Innovation for Circular Economy (BMI4CE) is a pathway to circularity. BMI4CE analysis is essential for identifying the key elements of BMs to reach a higher level of circularity than incumbent firms and support industries' transition toward CE (Henry et al., 2020).

Among the players, BMI4CE can be adopted by incumbent firms or startups with different challenges. On the one hand, incumbent companies must reconfigure, adapt or even change their $\mathrm{BM}$, rethinking and design their business model to ensure it is responsive to CE challenges (Urbinati et al., 2017; Upadhyay et al., 2021b). On the other hand, startups have the opportunity to create innovative BMs based on CE principles from the beginning.

Besides the differences between the challenges faced by incumbents and startups in aligning their BMI to circular logic, startups play an important role in the necessary shift toward sustainability (Henry et al., 2020). Circular-born startups can effectively respond to current unsustainable trajectories, playing a role in shaping new market logic in different industries and shifting toward sustainability (Bocken et al., 2017).

However, to the best of our knowledge, the research of innovative and circular BMs of startups lacks specific attention. The transition of incumbent companies to $\mathrm{CE}$ has received great attention in the academy in the last years. Previous research has identified opportunities and barriers to incumbent companies transition to CE (Upadhyay et al., 2021b); analyzed the transition of operating companies toward new business models (Urbinati et al., 2020); and proposed a framework to explain how incumbents can adapt existing BMs or create new value propositions (Urbinati et al., 2017). As much as the previous literature has deepened the discussion on the transition from linear to circular BMs, there is a gap in scientific knowledge about BMs that are circular from inception.

To fulfill this gap, the present study aimed to identify the key elements of startups' BMI4CE. Exploratory and descriptive research was conducted by a multiple case study, analyzing startups based in Europe, North America, and Asia, whose sustainable BMIs are promising for the fashion industry (Copenhagen Fashion Summit, 2019b). The fashion industry seems to be an appropriate and relevant study context for BMI4CE. Innovative and sustainable BMs have been used and analyzed from different approaches across many industries (Pieroni et al., 2019). However, it still needs to be deepened in specific sectors, central to the negative environmental effect, such as the fashion industry (Galleli et al., 2015). This industry presents important environmental and social impacts, resulting from the dominant fast fashion business logic, the production process's characteristics, and the value chain's specificities (Lueg et al., 2013; Niinimäki et al., 2020). Therefore, new paradigms are needed to change the logic of the industry and make it more sustainable. Additionally, there are specificities on $\mathrm{CE}$ implementation in fashion companies (Colucci and Vecchi, 2020). Understanding BMI4CEs in this industry can help predict its technological directions, identifying innovative market trends and sustainable solutions.

From the results, the key elements of the BMI4CEs of these startups are presented, contributing to the theoretical development of innovation management and CE fields through inter-relational analysis (i.e., BMI4CE). We identified differences between the product-based and service-based BMI4CEs of fashion startups. The proposed solutions are aligned with the closed-loop value creation strategy and focus on value retention at the material level. Furthermore, we identified that the social dimension of sustainability is still little explored in the BMI4CEs of the fashion startups analyzed.

We raised five theoretical propositions that can boost the BMI4CEs of fashion startups, highlighting the need to consider the social dimension of sustainability and the relevance of new social and sustainable technologies to enable CE. We also present a framework to summarize our contributions.

Besides research on BMI4CE has increased in recent years, most studies are still theoretical (Diaz Lopez et al., 2019; Centobelli et al., 2020). Our research attends the call of Pieroni et al. (2019) for more empirical investigations to the maturation of theory in this study area. Besides, we contribute to the literature investigating how companies create and capture value in business aligned to the $\mathrm{CE}$ basis. The findings present innovative supply chain, technology, and business strategy trends, pointing out possibilities for newcomers and companies to transition toward more sustainable practices. Finally, we have empirically tested the categories described for literature to evaluate BMI4CE, collaborating to develop new instruments specific to the CE context.

\section{THEORETICAL BACKGROUND}

This section presents CE's conceptual characteristics on its interrelation with sustainability (Pieroni et al., 2019), bringing this discussion to the fashion industry as an investigative locus. Thus, the characteristics inherent to BMIs are presented (Teece, 2010), allowing a better understanding and analytical deepening of BMI4CE. Then, the role of startups in developing innovations in the fashion industry is explored.

\section{Circular Economy and Sustainability in the Fashion Industry}

Circular Economy can be considered a driver for sustainability (Geissdoerfer et al., 2017; Kirchherr et al., 2017), representing the most advanced and recent manifestation for a paradigm shift toward sustainability (Prieto-Sandoval et al., 2018). On the constitutive aspects, CE is a socio-economic model that opposes the linearly prevailing global economic logic, whose pattern was the basis for economic development. The linear logic is characterized by extracting natural resources and transforming them into products, consumption, and disposal, generating 
environmental impacts (Ghisellini et al., 2016; Agyemang et al., 2018).

$\mathrm{CE}$ is a complex and challenging proposal, demanding changes in the status quo of business and economy. It requires a system of reprogramming as a whole, with all stakeholders' involvement and accountability, and shifts in social interrelationships, not only in business models (Merli et al., 2018; de Jesus et al., 2019). CE differs from other sustainability approaches by proposing restorative and regenerative systems (Ghisellini et al., 2016) with strategies based on design, closedloop systems (Murray et al., 2017), and resource and material efficiency (Nußholz, 2017).

Essentially, CE can be defined as "an economic model wherein planning, resourcing, procurement, production and reprocessing are designed and managed, as both process and output, to maximize ecosystem functioning and human wellbeing" (Murray et al., 2017, p. 377). Thus, it proposes a reduction of consumption, the extension of the resources, materials, and goods life cycle, and replaces ownership by access, adopting BMs aimed at the Product-Service System (PPS) (Manninen et al., 2018; de Jesus et al., 2019; Hofmann, 2019; Fernandes et al., 2020).

Circular principles are based on i) design out of waste and pollution; ii) regenerate natural systems; and iii) extend materials lifetime (Ellen MacArthur Foundation, 2021). The design encompasses long-lasting both products and processes. It proposes redesigning the production and consumption process, from the stage of conception, product design, supply chain development, production, distribution chain, consumption, and disposal or reuse (Murray et al., 2017). The closed-loop supply chains (Nußholz, 2017; Lüdeke-Freund et al., 2019) seek to minimize the exploitation of organic raw material and replace the concept of "end-of-life" product (Hofmann, 2019) through a more efficient and effective economic system, including production, distribution, and consumption (Pieroni et al., 2019). Implementing repair, maintenance, reuse, redistribution, recycling, refurbishment, and remanufacturing practices extends the materials' lifetime (Linder and Williander, 2017; Hofmann, 2019).

The implementation of circular solutions for sustainability can be even more challenging in industries that rely heavily on linear logic, such as the fashion industry, one of the largest industries worldwide. Over the last two decades, its growth has been driven by the fast fashion business model, based on the massification of trends, large-scale production, and consumption of short-lived fashion items, low service life, low selling price, fast psychological obsolescence, and fast disposal (Armstrong et al., 2015; Todeschini et al., 2017).

The garment production process itself is characterized by the high intensity of natural resource use, considering both the raw materials and the impacts of the production process (energy use, chemicals) and the stages of distribution, consumption (use), and disposal are generators of high pollution. There is intensive water, energy, chemicals, and pesticides to produce raw materials and textiles (Pedersen et al., 2018). Thus, added to the potential for pollution and impact of the production process, the fast fashion model increased sales volume, resulting in increased i) production of goods, ii) consumption of natural resources, and iii) volume of discarded items, with a consequent increase in social, economic and environmental impacts (Armstrong et al., 2015).

Another challenging issue is the organization of the fashion industry production chain. Global brands dominate the market, giving high concentration and dominance of large competitors (Barnes and Lea-Greenwood, 2006). The operation takes place through a broad, global, dispersed and fragmented supply chain and distribution, often with a country outside production strategy, seeking a low cost, shorter production times, and larger scale (de Brito et al., 2008; Kozlowski et al., 2015). Due to its fragmentation, there is a significant increase in the risks arising from social problems, such as child or slave labor, labor exploitation, and precarious labor relations due to the outsourcing of production to emerging countries, occurring by the pressure to maintain low production costs (Lueg et al., 2013; Pedersen et al., 2018).

These challenges facing the fashion industry value chains highlight the relevance of implementing pro-sustainability practices, which is why $\mathrm{CE}$ emerges as a relevant strategy for systemic change in this industry (Pieroni et al., 2019). Initiatives as zero waste product and process design, development of sustainable textiles from waste and alternative materials, production of long-lasting textiles, and reduction of waste and energy consumption are examples of $\mathrm{CE}$ implementation by the fashion industry (Todeschini et al., 2017; Colucci and Vecchi, 2020).

\section{Business Model Innovation for Circular Economy}

For a better understanding of BMI4CE, it is necessary first to understand Business Model (BM), and Business Model Innovation (BMI) concepts since studies on these usually lack clear conceptualizations (Foss and Saebi, 2017). BM can be understood as a holistic and interconnected system within the value chain, based on the goods developed and offered to consumers (Teece, 2010). Thus, BM can be defined as "the content, structure, and governance of transactions designed to create value through the exploitation of business opportunities" (Amit and Zott, 2001, p. 511).

However, a BM's not just focusing on creating value for consumers. Together, it is necessary to have value appropriation by consumers' willingness to buy (pay), ensuring long-term business survival and profit (Teece, 2010). BM represents how a company creates and captures economic value (Shafer et al., 2005; Björkdahl, 2009; Bowman et al., 2019). As the business environment is unstable and often unpredictable, a BM needs to adapt to new market circumstances or dynamics to support the solution for social-economic problems and the commercialization of this solution (Chesbrough, 2010). Thus, it leads to innovations in BM.

It is from this perspective that recent discussions on BMI emerge in the CE literature. Learning about market conditions induces innovations in the way companies create and appropriate economic value (McGrath, 2010; Linder and Williander, 2017). BMI "occurs when firms improve their existing business models 
or introduce new ones" (Fjeldstad and Snow, 2018, p. 36) by restructuring the model components or by creating new business structures to offer unique value propositions for a given market segment (Foss and Saebi, 2017). Although innovations in goods, services, and processes are not synonymous with innovation in BM (Geissdoerfer et al., 2018b), BMIs make it possible for companies to market these innovations effectively (Teece, 2010). In addition, they are responsible for market disruptions, leading companies to stay competitive in their segments (Bowman et al., 2019; Schiavi et al., 2019).

CE principles can be introduced into BMs by incumbent firms or guide startups' BMs, enabling companies to develop business model innovation for the Circular Economy (BMI4CE) (Pieroni et al., 2019). The alignment of value creation structures and value chains with the CE precepts leads to more sustainable production and consumption systems (Hofmann, 2019) by rethinking and redefining the creation, capture, and delivery of value (Nußholz, 2017; Lüdeke-Freund et al., 2019).

A BMI4CE seeks to offer value by reducing, reusing, and recycling materials in consumption, distribution, or production processes through design, closed-loop systems, and resource and material efficiency (Nußholz, 2017; Prieto-Sandoval et al., 2018). Urbinati et al. (2017) advocate that the circular business models have three main dimensions that encompass decisions and actions to circular business definition and implementation: value creation, value transfer and value capture. In BMIs aligned with $\mathrm{CE}$ precepts, the value is tangible and intangible or non-monetary (Centobelli et al., 2020), resulting in uncertainties, risks, and challenges to balance all three dimensions of sustainability (Mrkajic et al., 2019).

The consumer assumes a prominent role in circular business models (Urbinati et al., 2020). Consumers are involved as both obtainers and providers of resources. Their participation in purchasing, product care and maintenance, in the destination of items and post-use waste, place them as key stakeholders (Camacho-Otero et al., 2018). Furthermore, the value associated with a product or service is no longer lost after its usage by customers, which demands involvement and interaction (Centobelli et al., 2020).

\section{Startups as Innovation Precursors for Circular Economy in the Fashion Industry}

Startups are technology-based nascent companies with highly innovative performance and potential (Weiblen and Chesbrough, 2015; Dullius and Schaeffer, 2016; Kohler, 2016). They are responsible for introducing disruptive innovations that can change markets and industries, playing "a key role in the innovation process by exploring and exploiting new ideas, market opportunities, and disruptive technologies" (Pisoni and Onetti, 2018, p. 26).

This whole innovative process characterizes startups' operation in an "explore and adapt" model, while traditionally established companies operate in a "plan and execute" model (Freytag, 2019). Startups are in the early conceptualization stage to develop new goods or services and implement new BMs (Pisoni and Onetti, 2018). Two stages characterize the initial phase: "search for business" (development stage) and "growth for business" (sales stage) (Freytag, 2019). The first stage involves creating innovative prototypes for market validation and identifying potential consumers. Then, after the sales start, the second stage begins, where the BM has validation, and the startup seeks rapid growth toward a scale-up process (Freytag, 2019).

By creating value for the target audience and capturing value from this, a startup's primary goal is to shape a promising BM that enables such value streams to occur effectively (Bortoloni et al., 2021). Innovation is essential for the effectiveness of startups' BMs, especially in the fashion industry (Todeschini et al., 2017). The relevance of born-sustainable startups in this context is emphasized. They present innovative and practical solutions to social and environmental problems and are described as pioneering in applying new technologies in their areas, with a greater propensity for disruptive and radical innovations (Demirel et al., 2017).

The startups with BMs aligned with CE principles are called circular-born companies (Colucci and Vecchi, 2020). They present business operations based on sustainability values and principles, collaboration, and innovation relevant to sustainable practices in the fashion industry (Todeschini et al., 2017). As startups have a high speed of technology propagation in the market, it could allow the innovations developed by them to be disseminated quickly in the fashion industry, generating transformations toward CE.

\section{METHOD}

We conducted a qualitative multiple case study to investigate the BMI4CEs of startups in the early stage of the business lifecycle. We chose a multiple case study strategy to examine a reallife and contemporary phenomenon in its natural setting (Yin, 1994). We seek to understand multiple and different perspectives from empirical observation, analyzing differences and similarities among distinctive and representative cases (Carrillo-Hermosilla et al., 2010; Ranta et al., 2021). As BMI4CE is still an incipient study theme, the multiple case study strategy is indicated for exploring the theme and identifying other emerging issues (Sigglekow, 2007). Besides, the investigation of multiple cases allows us to generalize the study's findings (Eisenhardt and Graebner, 2007).

As the focus is on BMI4CEs, it was necessary to select relevant cases in the fashion industry to understand key elements of their BMIs. We selected the ten startups participating in the Future Lab of Copenhagen Fashion Summit 2019. Copenhagen Fashion Summit is an annual event focused on highlighting the changing needs of the fashion industry's production, consumption, and marketing. It is the leading forum for fashion industry contributors on sustainability, assuming that sustainability must be rethought in this industry and driven by innovations, particularly in BMs. The event seeks to underscore new business forms to address challenges such as climate change, human rights, and the scarcity of natural resources in the fashion industry (Copenhagen Fashion Summit, 2019a). 
Annually, Future Lab selects ten new businesses with the potential to change practices for achieving sustainability in the fashion industry through new technologies and BMs. The ten startups represent innovative BMs, with actions focused on developing new sustainable materials, new clean technologies, and integration between actors in the supply chain, i.e., practices driving CE in the fashion industry. Thus, all ten cases are relevant to the analysis proposed in this research.

The Future Lab has both product-based and servicebased startups, representing BMIs recognized for the industry under analysis and describing the diversity of BMI4CEs. These startups are located in developed countries from three continents (North America, Europe, and Asia). From different countries, they allow a broader understanding of the elements of BMI4CEs in the fashion industry. Table 1 presents the selected startups.

In this research, startups constitute the units of analysis. We analyzed secondary data available on startups' websites, profiles, and social media (Facebook, Instagram, and Linkedin), collected in July 2019. We also have tried to understand better certain characteristics of the BMI4CEs that were not found from the data collected online (i.e., information of monetization and positions and actions related to the social dimension). We emailed all the ten companies on July 18, 2019, inviting them to participate in academic research about business model innovation in the fashion industry. Just two startups answered: one informing unwillingness to participate and the other answering our questions. A new email was sent to the other companies on July 30,2019 , without additional answers. Due to the unwillingness of companies to participate, we focused our efforts on analyzing the available secondary data.

The researchers analyzed the information displayed online, collected manually the central points related to the research objective, and organized the data in Excel (see Table 3). We do not identify documents in Word or PDF format for download, so we have analyzed the content online. Consequently, we do not use any specific content analysis software because there wasn't data in file format. The data collected were the base to analyze information and characteristics of the startups, elements of their BMIs, and how they contributed to the adoption of CE in the fashion industry.

The dimensions of analysis emerged from the instruments proposed to BMI4CEs analysis by Lüdeke-Freund et al. (2019) and Lewandowski (2016). The instrument presented by Lewandowski (2016) is one of the most relevant for analyzing and developing BMI4CEs (Pieroni et al., 2019). It is an adaptation of the Canvas instrument (Osterwalder and Pigneur, 2010), commonly used in BMI analysis. In addition, we included the dimensions from the instrument proposed by Lüdeke-Freund et al. (2019) to increase the instrument's robustness.

We proceed with adaptations to arrive at the research's final instrument, considering our study focus on circular-born startups. First, we have identified the main CE principles involved in the BMI value offer. Regarding the value capture, just the

TABLE 1 | Fashion startups analyzed in the study.

\begin{tabular}{|c|c|c|c|c|}
\hline Startup & Country & Foundation & Business area & Business value proposition \\
\hline Algalife & United Arab Emirates & 2016 & $\begin{array}{l}\text { Development of clean-tech } \\
\text { new materials }\end{array}$ & $\begin{array}{l}\text { Biodegradable pigments and fibers developed } \\
\text { from renewable microorganisms }\end{array}$ \\
\hline Circular Fashion & Germany & 2017 & $\begin{array}{l}\text { Digital technology (platform) } \\
\text { to connect value chain }\end{array}$ & $\begin{array}{l}\text { Digital platform (software) that enables } \\
\text { information flow between material suppliers, } \\
\text { brands, customers, and recyclers }\end{array}$ \\
\hline Circular Systems & USA & 2017 & $\begin{array}{l}\text { Development of clean-tech } \\
\text { new materials }\end{array}$ & $\begin{array}{l}\text { High-value textile fibers for the fashion industry } \\
\text { produced from agricultural, industrial, and } \\
\text { post-consumption waste }\end{array}$ \\
\hline Dimpora & Switzerland & 2019 & $\begin{array}{l}\text { Development of clean-tech } \\
\text { new materials }\end{array}$ & $\begin{array}{l}\text { High performance and sustainable, functional } \\
\text { membranes for outdoor enthusiasts }\end{array}$ \\
\hline Gibbon & Singapore and Amsterdam & 2016 & $\begin{array}{l}\text { Digital technology (platform) } \\
\text { to the rental market }\end{array}$ & $\begin{array}{l}\text { Digital clothing rental platform that connects } \\
\text { excess inventory of brands and retailers to } \\
\text { travelers, enabling a luggage-free travel } \\
\text { experience }\end{array}$ \\
\hline Monochain & England & 2018 & $\begin{array}{l}\text { Digital technology (platform) } \\
\text { to the second-hand market }\end{array}$ & $\begin{array}{l}\text { A multi-user blockchain platform that offers } \\
\text { end-to-end traceability to converge primary } \\
\text { and retail clothing markets }\end{array}$ \\
\hline Nature Coatings & USA & 2017 & $\begin{array}{l}\text { Development of clean-tech } \\
\text { new materials }\end{array}$ & $\begin{array}{l}\text { High-performance black pigments made from } \\
\text { wood waste }\end{array}$ \\
\hline Reflaunt & England & 2017 & $\begin{array}{l}\text { Digital technology (platform) } \\
\text { to the second-hand market }\end{array}$ & $\begin{array}{l}\text { A technology platform that unites first and } \\
\text { second-hand fashion retail markets }\end{array}$ \\
\hline Resortecs & Belgium & 2016 & $\begin{array}{l}\text { Recycle (disassembly of } \\
\text { apparel) }\end{array}$ & $\begin{array}{l}\text { Equipment that facilitates disassembly of } \\
\text { garments by dissolving metal components at } \\
\text { high temperature }\end{array}$ \\
\hline Vegea & Italy & 2016 & $\begin{array}{l}\text { Development of clean-tech } \\
\text { new materials }\end{array}$ & $\begin{array}{l}\text { Vegetable leather produced from agricultural } \\
\text { waste from grape peel }\end{array}$ \\
\hline
\end{tabular}


cost structure was evaluated since it was not possible to analyze the "Revenue sources". The startups were in their early-stage lifecycle, focusing on product development and fundraising from investors-i.e., they are not trading yet-(Spender et al., 2017). The dimension "Adoption factors" (Lewandowski, 2016) was excluded from the analysis because it concerns general factors needed to change from a linear to a circular system by incumbent companies. Table 2 presents the final analysis dimensions and their definitions.

A content analysis was applied to analyze the online data, coded according to the seven analysis dimensions. The researchers' reflective analysis supported the relevance of the cases to achieve the investigation objectives (Creswell, 2010; Nascimento and Steinbruch, 2019). Moreover, the diversity of cases (from three continents) analyzed herein characterizes a triangulation of evidence sources, as advocated by Bruning et al. (2018). This type of triangulation also occurred by comparing information available on the startups' websites and social networks, online media (other sources such as magazines), and the Copenhagen Fashion Summit website. We also adopted the researchers' triangulation (Creswell, 2010), which consisted of data analysis by each researcher individually and then collectively discussed for a common understanding. This entire methodological path ensured reliability in the results.

\section{RESULTS}

The analyzed cases present product-based and service-based BMs with different characteristics and strategies in resource usage, customer segmentation, value proposition, operation, value creation, and cost structure. Table 3 summarizes the

TABLE 2 | Dimensions of BMI4CE analysis.

\begin{tabular}{|c|c|c|}
\hline Dimension & Definition & Reference \\
\hline Type of offer & $\begin{array}{l}\text { How the startups offer the benefits to } \\
\text { costumers }\end{array}$ & $\begin{array}{l}\text { Lüdeke-Freund et al., } \\
2019\end{array}$ \\
\hline CE principle & $\begin{array}{l}\text { Circular principles are i) design out of } \\
\text { waste and pollution; ii) regenerate } \\
\text { natural systems; and iii) extend } \\
\text { materials lifetime }\end{array}$ & $\begin{array}{l}\text { Ellen MacArthur } \\
\text { Foundation, } 2021\end{array}$ \\
\hline $\begin{array}{l}\text { Customer } \\
\text { segments }\end{array}$ & $\begin{array}{l}\text { Corresponds to the target customers } \\
\text { and is part of the value proposition } \\
\text { component }\end{array}$ & $\begin{array}{l}\text { Lewandowski, 2016; } \\
\text { Lüdeke-Freund et al., } \\
2019\end{array}$ \\
\hline $\begin{array}{l}\text { Value } \\
\text { proposition }\end{array}$ & $\begin{array}{l}\text { Comprises the incentives and benefits } \\
\text { offered to the target customers }\end{array}$ & $\begin{array}{l}\text { Lewandowski, 2016; } \\
\text { Lüdeke-Freund et al., } \\
2019\end{array}$ \\
\hline Key activities & $\begin{array}{l}\text { Focused on increasing performance } \\
\text { by creating, offering, and } \\
\text { delivering the value propositions }\end{array}$ & Lewandowski, 2016 \\
\hline $\begin{array}{l}\text { Value creation } \\
\text { process }\end{array}$ & $\begin{array}{l}\text { How the activities developed by the } \\
\text { startup create value }\end{array}$ & $\begin{array}{l}\text { Lewandowski, 2016; } \\
\text { Lüdeke-Freund et al., } \\
2019\end{array}$ \\
\hline Cost structure & $\begin{array}{l}\text { It is part of the value capture and } \\
\text { comprises the costs incurred when } \\
\text { operating the business model }\end{array}$ & $\begin{array}{l}\text { Lewandowski, 2016; } \\
\text { Lüdeke-Freund et al., } \\
2019\end{array}$ \\
\hline
\end{tabular}

main characteristics of the 10 BMI4CEs, based on the analysis dimensions.

Product-based BMs were focus on closed-loop systems, presenting as value proposition i) waste reuse to make new materials by processing and recycling, ii) use of renewable sources of fiber and pigment manufacturing resources, and iii) material design, developing fibers with higher performance and durability and less environmental impact in the production process. The customer segmentation of the product-based BM analyzed was mainly another business (B2B); just one case (Dimpora) presented a solution to the final consumer (B2C).

BMs based on circular services focused on closed-loop and reduction of materials' use and consumption strategies. We found value propositions built on i) product-service system and ii) digital solutions to the supply chain management and clothes reuse. The digital solutions found were Blockchain and Artificial Intelligence technologies. Platforms for re-selling clothes after first use (i.e., second-hand market) and clothing rental are examples of clothing reuse BMs.

All service-based BMs analyzed target multi-level relationships (B2B2C), demonstrating innovation in clothing resale BM. Traditionally, the second-hand resale business has focused on the final consumer. However, the studied cases target manufacturer brands and indirectly on the final consumer. Monochain and Reflaunt offer the traceability of resale items, which allows the environmental monitoring of the item and its time of use, consumer profile, counterfeiting of parts and brands, and consequent better control of the brand image. It brings an innovative value proposition in the second-hand clothes market, offering a solution to brand management that delivers value to retailers and fashion brands. Other benefits are the brand's connection with consumers - especially the Millennials generation, intense technology users and monitoring emerging consumer macro-trends.

The value proposition types were evaluated by the dimensions proposed by Lüdeke-Freund et al. (2019). Among the studied cases, four BM's value propositions were not listed in the original instrument: Algalife, Dimpora, Circular Fashion, Monochain, and Reflaunt. Algalife and Dimpora develop innovative raw materials to replace existing ones in the market. Algalife produces pigments and fibers from renewable organic material, and Dimpora proposes new raw materials with low environmental impact in production and use. Thus, we suggest a new category to classify the value proposition of these two companies, named "Development of new materials". The category encompasses developing, producing, and/or commercializing new raw materials for clothes-renewable alternatives-instead of traditional non-renewable raw materials.

The value proposition of Circular Fashion, Monochain, and Reflaunt is not encompassed by just one category. All cases presented one of the value propositions described by LüdekeFreund et al. (2019) and another non-described. In the Circular Fashion case, we have identified the value proposition "facilitate collaboration"; in the Monochain and Reflaunt cases, the option “Take-back management". Additionally, they all offer solutions to connecting, tracking, and/or managing the value chain, from raw material producer to consumer. The Circular Fashion solution 
TABLE 3 | Results from fashion startups' BMI4CE investigation.

\begin{tabular}{|c|c|c|c|c|c|c|c|}
\hline \multirow[b]{2}{*}{ Startups } & \multicolumn{7}{|c|}{ Categories } \\
\hline & $\begin{array}{l}\text { 1. Business } \\
\text { type }\end{array}$ & $\begin{array}{l}\text { 2. Resources } \\
\text { usage } \\
\text { strategy }\end{array}$ & $\begin{array}{l}\text { 3. Customer } \\
\text { segmentation }\end{array}$ & $\begin{array}{l}\text { 4. Value } \\
\text { proposition type }\end{array}$ & $\begin{array}{l}\text { 5. Operation } \\
\text { form }\end{array}$ & 6. Value creation process & 7. Cost structure \\
\hline $\begin{array}{l}\text { Circular } \\
\text { Systems }\end{array}$ & Product & Closed-loop & $\mathrm{B} 2 \mathrm{~B}$ & $\begin{array}{l}\text { Products, } \\
\text { materials or waste } \\
\text { used as } \\
\text { production inputs }\end{array}$ & Circular Supply & $\begin{array}{l}\text { Recycling of products, } \\
\text { materials, waste; upcycling }\end{array}$ & $\begin{array}{l}\text { Product and process } \\
\text { development; labor; waste } \\
\text { handling, processing, } \\
\text { manufacturing }\end{array}$ \\
\hline Algalife & & & & $\begin{array}{l}{ }^{*} \text { Development of } \\
\text { technology: } \\
\text { renewable organic } \\
\text { raw material }\end{array}$ & Circular Supply & Material Design & $\begin{array}{l}\text { Product and process } \\
\text { development; labor; } \\
\text { manufacturing }\end{array}$ \\
\hline $\begin{array}{l}\text { Nature } \\
\text { Coatings }\end{array}$ & & & & $\begin{array}{l}\text { Products, } \\
\text { materials or waste } \\
\text { used as } \\
\text { production inputs }\end{array}$ & Circular Supply & Waste recycling; upcycling & $\begin{array}{l}\text { Product and process } \\
\text { development; labor, waste } \\
\text { handling; processing and } \\
\text { manufacturing }\end{array}$ \\
\hline Resortecs & & & & $\begin{array}{l}\text { Waste Processing } \\
\text { and Recycling }\end{array}$ & $\begin{array}{l}\text { Facilitate resource } \\
\text { recovery through } \\
\text { recycling }\end{array}$ & $\begin{array}{l}\text { Product and material } \\
\text { recycling }\end{array}$ & $\begin{array}{l}\text { Product and process } \\
\text { development; labor }\end{array}$ \\
\hline Vegea & & & & $\begin{array}{l}\text { Products, } \\
\text { materials or waste } \\
\text { used as } \\
\text { production inputs }\end{array}$ & Circular Supply & Waste recycling; upcycling & $\begin{array}{l}\text { Product and process } \\
\text { development; labor, waste } \\
\text { handling; processing and } \\
\text { manufacturing }\end{array}$ \\
\hline Dimpora & & & $\mathrm{B} 2 \mathrm{C}$ & $\begin{array}{l}{ }^{*} \text { Development of } \\
\text { technology - new } \\
\text { material for clothes }\end{array}$ & Circular Supply & Product and material design & $\begin{array}{l}\text { Product and process } \\
\text { development; labor; } \\
\text { processing, manufacturing }\end{array}$ \\
\hline $\begin{array}{l}\text { Circular } \\
\text { Fashion }\end{array}$ & Service & Closed-loop & B2B2C & $\begin{array}{l}\text { Facilitate } \\
\text { Collaboration + } \\
\text { *Value Chain } \\
\text { Management/ } \\
\text { Tracking }\end{array}$ & $\begin{array}{l}\text { Not described: } \\
\text { enable value chain } \\
\text { collaboration and } \\
\text { management }\end{array}$ & $\begin{array}{l}\text { Connecting suppliers and } \\
\text { customers, providing } \\
\text { access to services and } \\
\text { product-based results }\end{array}$ & $\begin{array}{l}\text { Product and process } \\
\text { development; labor; supply } \\
\text { risk, *transactional }\end{array}$ \\
\hline Gibbon & & $\begin{array}{l}\text { Reduce } \\
\text { materials use } \\
\text { and } \\
\text { consumption }\end{array}$ & & $\begin{array}{l}\text { Product-Service } \\
\text { Based Functions }\end{array}$ & $\begin{array}{l}\text { Sharing: availability } \\
\text { based PPS }\end{array}$ & $\begin{array}{l}\text { Providing access to product } \\
\text { functionality; meeting } \\
\text { excessive capacities with } \\
\text { insufficient capacities }\end{array}$ & $\begin{array}{l}\text { Labor; Repair, Maintenance } \\
\text { and Control; Transportation } \\
\text { and Logistics; Supply Risk }\end{array}$ \\
\hline Monochain & & & & $\begin{array}{l}\text { Take-back } \\
\text { management }+ \\
{ }^{*} \text { Post-use product } \\
\text { tracking - cycle } \\
\text { closure }\end{array}$ & $\begin{array}{l}\text { Optimization: } \\
\text { resale of used } \\
\text { products }\end{array}$ & $\begin{array}{l}\text { Providing product-based } \\
\text { access to services and } \\
\text { results; connecting } \\
\text { suppliers and customers }\end{array}$ & $\begin{array}{l}\text { Product and process } \\
\text { development; labor }\end{array}$ \\
\hline Reflaunt & & & & $\begin{array}{l}\text { Take-back } \\
\text { management }+ \\
{ }^{\star} \text { Post-use product } \\
\text { tracking - cycle } \\
\text { closure }\end{array}$ & $\begin{array}{l}\text { Optimization: } \\
\text { resale of used } \\
\text { products }\end{array}$ & $\begin{array}{l}\text { Providing product-based } \\
\text { access to services and } \\
\text { results; Connecting } \\
\text { suppliers and customers }\end{array}$ & $\begin{array}{l}\text { Product and process } \\
\text { development; labor }\end{array}$ \\
\hline
\end{tabular}

*Value proposition type not listed on previous category instrument used in this research.

focuses on all value chains and Monochain and Reflaunt tracking the value proposition's product post-use phase. We denominate this new category as "Value chain management".

The analysis indicated an emphasis on environmental aspects regarding companies focused on the development of clean-tech new materials. On the other hand, companies that offer services through digital technology seem to focus their proposal on marketing, economic, and environmental aspects. In all cases, the social dimension received less attention in BMs descriptions and value proposition.
Regarding the BMs operation form, the cases of startups that offer products are mainly based on circular supply, and one of the cases seeks to facilitate resource recovery through recycling (Resortec). Among the service-based startups, Gibbon's $\mathrm{BM}$ is based on resource optimization through the resale of used products and sharing based on Product-Service System (PSS) and Monochain and Reflaund on optimization. Circular Fashion could not be classified in the options proposed by Lewandowski (2016) pp. 8-9. Thus, we suggest a new operation type: "enable collaboration and value chain management". 
The value creation processes of the product-based BM cases studied were "Recycling of products, materials, waste" and "Designing products, components and materials", both described by the previous literature. Surprisingly, only one case could be classified among the service-based BMs on the value creation process options proposed by Lüdeke-Freund et al. (2019). Thus, we presented two new options to describe Gibbon, Monochain, and Reflaunt value creation process: "Meeting excessive capacities with insufficient capacities" and "Providing product-based access to services and results".

Finally, the cost structure is an essential dimension for BMI4CE success, considering the challenge of startups to monetize the operation and obtain an economic return, especially if they operate in technological innovation areas linked to sustainability (Demirel et al., 2017). We found that startups' BM4CEs present costs mostly related to product and process development and labor, which was expected in a study about startups. Other costs associated were i) waste handling, processing, and manufacturing; ii) supply chain risk; iii) transportation and logistics; iv) repair and maintenance; and v) control. Transactional costs are related to logistics actions, relations, and strategies in supply chain management (Talay et al., 2018), affecting Circular Fashion's BM. Thus, transactional costs were included as a new category.

\section{DISCUSSION}

The results presented allowed us to generate some theoretical propositions that advance knowledge in the area. First, the propositions and theoretical and empirical basis are presented, followed by a framework integrating academic insights and research findings.

We have identified both product and service-based BMI guiding the pathway to implementing circularity in the fashion industry. Our results suggest that product-based and servicebased BMs have different characteristics and demand-specific strategies. Previous research already has identified differences in circular business implementation in the manufacturing and service sectors (Esposito et al., 2017; Upadhyay et al., 2019). Comparatively, service and manufacturing sectors need to develop distinct capabilities and competencies (Upadhyay et al., 2019).

We found that product-based BMs were focused on closedloop systems, mainly on the $\mathrm{B} 2 \mathrm{~B}$ segment. Products need to be manufactured without waste and minimum energy, water and raw material use (Lewandowski, 2016). The manufacturing sector also deals with the post-life product through reverse logistics, reuse, refurbishment and other circular strategies. Consequently, new production technologies are essential to implement a circular manufacturing system.

The analyzed BMs based on circular services are dedicated to closed-loop and reduction of materials' use and consumption strategies based on digital solutions. Some of the service-based BMs can be described as a Product-Service System (PSS), as indicated in the literature with sustainable and circular BMs (Tukker, 2015; Nußholz, 2017; Hofmann, 2019). PSS is a way to capture value by disconnecting the value from the material consumption (Maxwell and van der Vorst, 2003), replacing personal ownership and providing tangible and intangible services (Armstrong et al., 2015). Thus, PSS offers a value proposition that supports CE precepts (Urbinati et al., 2017). Hence, the first proposition from this multiple case study is:

Proposition 1. Service-based BMI4CEs tend to focus on innovative PSS in fashion startups, while product-based BMI4CEs concentrate on new production technologies for CE implementation.

Innovation and technology were identified in all studied cases, mainly digital technologies and material development technology. According to Pagoropoulos et al. (2017), digital technologies can help the transition toward CE and have been described in the literature as enabling closed-loop supply chains (Saberi et al., 2019). They are key elements to BMI because they support collaboration, sharing, optimization and decentralization processes (Urbinati et al., 2019; Upadhyay et al., 2021a). Digital technologies applied to CE implementation encompass diverse tech-based solutions such as digitalization, artificial intelligence, big data analysis, the internet of things, blockchain (Rosa et al., 2020; Upadhyay et al., 2021a). The results suggest that those digital technologies support CE principles through BMI4CE demands. Thus, the second proposition is:

Proposition 2. Emerging technologies, especially digital ones, enable the alignment of different CE principles in BMI4CE.

Being the closed-loop system essential to CE strategies (Murray et al., 2017), technology has also proved crucial for new materials, machines, and equipment in the industry that allows the implementation of circular production systems. In five analyzed cases (Algalife, Dimpora, Circular Fashion, Monochain, and Reflaunt), technology was applied to generate fibers, paints, and other raw materials from renewable organic fabric and organic waste.

Otherwise, previous studies emphasized EC actions linked to recycling or the use of recycled material in manufacturing industry operations (Jaeger and Upadhyay, 2020). The development of new materials reinforces the CE strategy of resource and material efficiency (Nußholz, 2017) and extends resources' useful life (Manninen et al., 2018). Therefore, another proposition is:

Proposition 3. Emerging technologies that base the BMI4CEs of fashion startups tend to favor developing innovative closedloop systems, enabling new sustainable materials creation and increasing efficiency in reusing waste.

We also identified that the environmental and economic dimensions receive priority attention in the analyzed BMI4CEs. Some of the BMs analyzed involve recycling, waste processing, and machine production. We seek information about the social dimension of BMs, location and conditions of production, employment and working conditions, and the management of social relationships in the chain. However, there is no mention of any of the websites and online materials consulted on the subject. For example, information about where the products 
were produced, the type of labor used, the type of employment contract, and the local economy's stimulus are essential to the social dimension of sustainability and were not found in the research data collected. Circularity presupposes BMs should consider not only the environment and the economy but also social needs (Ellen MacArthur Foundation, 2013). Our finding reinforces the criticism found in the literature about the CE's lack of attention to the social dimension of sustainability (Hofmann, 2019; Pieroni et al., 2019), supporting the following proposition:

Proposition 4. The innovative technologies of the BMI4CEs of fashion startups focus on environmental and economic sustainability, requiring attention to the social dimension developed (within companies) or adopted (from the market).

The analyzed BMs target consumers mostly i) other businesses (B2B) and ii) B2B2C relations. Only one of the cases (Dimpora) presents a final consumer solution (B2C). BMI4CEs can create monetary and non-monetary value involving multiple stakeholders' proactive and long-term perspective management (Geissdoerfer et al., 2018a). Thus, B2B or B2B2C relationships can be strategically valuable for moving from linear to circular systems, as they involve several agents along the value chain. Consequently, they can influence relationships in the chain, resulting in greater agents' involvement in circularity actions.

The influence of commercial relationships in the value chain drives companies under circular logic to prospect partners and buyers who also operate or are willing to operate under circularity principles. As a result, there is the formation of strategic networks, that is, CE networks. Thus, the CE paradigm drives companies that participate in the same value chain to incorporate sustainable practices. Collaboration in the chain also allows access to resources that companies do not own or have limited, which reduces transaction costs strategically (Talay et al., 2018). The supply chain can be a driver or a barrier to implementing CE (Tura et al., 2019; Ostermann et al., 2021) and play an important role in CE because it dictates the technology (e.g., machinery), processes and, consequently, limitations to new BMs. Considering the fashion industry supply chain as global, long, and complex, with multiple and diverse players (Niinimäki et al., 2020), we argue:

Proposition 5. CE supply management and value chain integration are key factors in implementing circularity in the fashion industry.

The set of propositions support the Theoretical Framework presented in Figure 1. This framework demonstrates each proposition represents a step that fashion startups can adopt to improve their BMI4CE. In Proposition 1, the startup's business type demands i) product prototyping and development efforts through new production technologies or ii) service experiences improved through PSS. The next step is Proposition 2, demonstrating that digital technologies are essential for integrating $\mathrm{CE}$ principles into the BMs of startups focused on products or services. Proposition 3 then highlights that integration efforts between CE principles and emerging technologies should drive closed-loop systems, new raw materials, and reuse of waste.

Both Propositions 2 and 3 are under the umbrella of Proposition 4: the development or adoption of emerging technologies needs to consider the social dimension of sustainability to boost CE practices. Based on this, startups can advance their contribution to sustainability in a triple bottom line perspective (Elkington, 1998), enabling the development of environmental and human practices - focused on nations' economic and social development. In this way, companies in the fashion industry can move toward the development and adoption of new social technologies, which requires a change of mindset in the formatting of BMI4CEs.

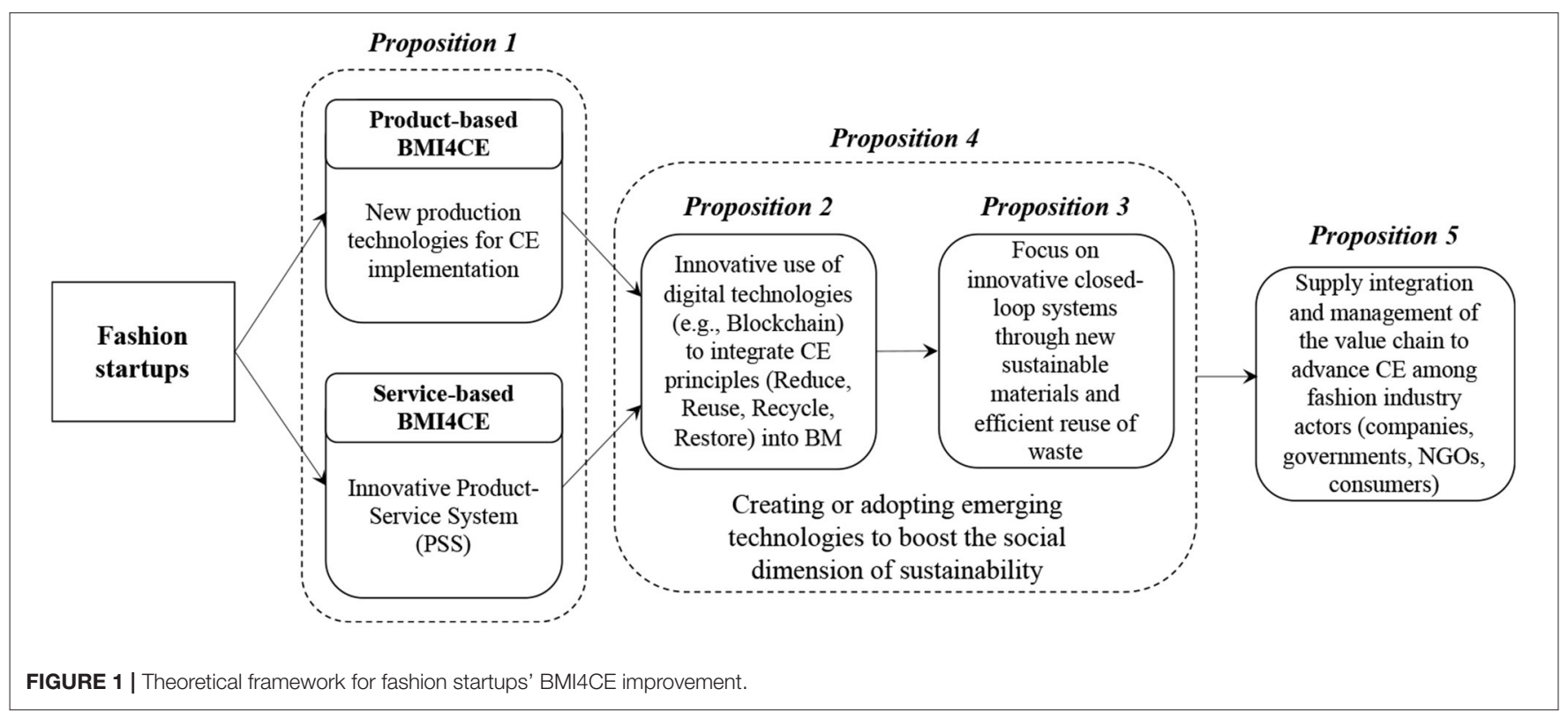


The last step, Proposition 5, demonstrates that startups' BMI4CE should consider and integrate actions and practices beyond organizational barriers. The very definition of circularity is dependent on the interaction between actors, whether B2B or $\mathrm{B} 2 \mathrm{C}$. These interactions form the value chain, encompassing i) the supply of sustainable materials for ii) clean production of fashion products with sustainable design, which facilitate iii) consumers reuse of products or iv) recycling of these products by companies into new value propositions, restarting the value chain. The interactions need to be considered in the conception of the BMs, whereas ways of integration among actors and the management of CE principles are necessary. In addition, other actors such as governments and NGOs can also influence the fashion value chain. Hence, BMI4CE in this industry needs to look at different actors and identify how they can interact with the startup's value proposition, positively impacting society.

\section{FINAL REMARKS}

Our results support the understanding that the key elements common to fashion startups' BMI4CEs are closed-loop and reduction of consumerism and materials use. Particular focus can also be found to reuse and new uses of materials and circular supply that can be improved through emerging and digital technologies. Thus, this research highlights new theoretical perspectives under an investigation area still little explored in the literature that allows broadening future academic discussions' horizons. It also enables managers in the fashion industry to better understand the functioning of BMI4CEs and the key elements needed for their effectiveness toward CE adoption in the industry. Finally, from this investigation, it is possible to highlight the key elements that other startups and incumbent firms in the fashion industry can use to improve the adoption of effective circularity practices.

\section{Theoretical Implications}

The literature consensus understands $\mathrm{CE}$ as a means to drive the adoption of sustainable practices (e.g., Ghisellini et al., 2016; Geissdoerfer et al., 2017; Bocken et al., 2018). However, CE is not yet seen as a starting point but as part of a transition process emerging from linear logic. CE stresses the need for a "functional service" model, in which the producer is aware and responsible for its impacts. Businesses must be thought to reduce the number of products in the market through reuse, recycling, and PSS (Ellen MacArthur Foundation, 2013) and reduce overall consumption in society (White et al., 2019). This logic is not contained in the "traditional" BM conception, the starting point for creating tools or instruments for BMI4CE analysis.

Therefore, we advance the frontier of knowledge in the CE literature by studying companies whose BMs were born-circular. As startups are born as enablers of innovation and technology, our findings demonstrate these companies' BMIs are essential for developing emerging and digital technologies regarding $\mathrm{CE}$ principles. BMI4CEs of the investigated cases highlight the need for innovative technologies, especially in materials science, enabling sustainable production and consumption. By indicating the key elements of the BMI4CEs of fashion startups and a set of theoretical propositions, we highlight new pathways to boost $\mathrm{CE}$, contributing fresh perspectives to the literature. On this, we call the attention of scholars and practitioners for the inclusion of sustainability social dimension on CE actions, which is underexplored in prior literature. Our theoretical findings can also have practical implications.

\section{Managerial Implications}

By indicating the key elements of BMI4CE, our findings can help startups' managers and entrepreneurs to improve their current business' BMI4CE or to planning future BMs. More precisely, the theoretical framework can help entrepreneurs build innovative BMs for newborn circular companies. For example, entrepreneurs should focus efforts on social technologies, a niche that needs deepening in the fashion industry. They can also develop BMs based on new and digital technologies to facilitate the integration among actors in the fashion value chain, strengthening the management of circularity practices in the chain.

Our contributions may also inspire incumbent companies looking to improve their BMs toward CE practices in fashion and other industries. Thus, managers of different industries, sizes, products, and services can use this paper's results to drive innovation for CE. Besides, business accelerators and incubators can adopt the propositions and theoretical framework in their mentoring programs to assist new businesses to build efficient BMI4CE.

Policymakers or international institutions pushing for a radical change of the production model in the fashion industry can adopt our propositions in developing public policies to boost CE. For instance, incentive policies can stimulate incumbent and new businesses to create innovative technologies in their BMs to meet the CE principles. Likewise, public officials and other policymakers can appropriate the directions presented in our contributions to improving regional innovation ecosystems by stimulating local startups' BMI4CEs key elements.

\section{Limitations and Future Research}

The use of secondary data generated certain limitations on the analytical deepening of this research. Moreover, even though research has focused on relevant and innovative cases, exploratory research does not guarantee the generalization of findings to all fashion industry companies. Consequently, the set of theoretical propositions developed in this study can be analyzed empirically in future investigations, allowing the generalization or not of this research's findings and evidence. Another limitation of the research comes from the study of startups in an early stage of development. It was not possible to identify, for example, which revenue sources the analyzed companies adopt because they are businesses that have not yet started their effective operation or are in the initial phase of operation.

The selection of BMI4CEs characterizes a research limitation since the analyzed startups are based in developed countries. However, the migration from a linear economy to a circular economy can be facilitated within these nations because of access to resources (e.g., knowledge and technology), regulations, and 
public policies that may influence and promote the formation of BMI4CEs in the fashion industry. Thus, further research may broaden through the quantity and/or diversity of cases and investigate startups' BMI4CE in developing countries, focusing on these nations' specificities and the characteristics that the fashion industry has in these countries (e.g., the production of the fashion industry is commonly based in developing countries). Also, new investigations may deepen the analysis proposed herein with the same cases through primary data collection.

As a methodological reflection, we can understand that current BM analysis instruments are adapted from linear logic (e.g., the ones we used in this research). However, if the CE wants to rethink and redefine how it creates, captures, and delivers value (Nußholz, 2017; Lüdeke-Freund et al., 2019), it would not be necessary to formulate new tools and instruments designed and created from the CE logic and theory? Such questioning is intriguing, requiring further deepening and discussion from the conduction of future investigations.

Consumers are an essential part of the chain because they decide the "value" of innovation. However, it appears that the analyzed businesses are chain-oriented. It is unknown how the consumer will be added to the system or how they will be responsible (or be held accountable) for their decisions and actions on fashion items purchase, maintenance, and disposal. Is it possible that innovation in the BMs, by itself, can influence and modify the value chain structure in the fashion industry toward CE? Thus, we suggest new research to develop these discussions.

\section{REFERENCES}

Agyemang, M., Kusi-sarpong, S., and Mani, V. (2018). Drivers and barriers to circular economy implementation: An explorative study in Pakistan's automobile industry. Manage. Decis. 57, 971-994. doi: 10.1108/MD-11-2018-1178

Amit, R., and Zott, C. (2001). Value creation in e-business. Strat. Manag. J. 22, 493-520. doi: 10.1002/smj.187

Armstrong, C. M., Niinimäki, K., Kujala, S., Karell, E., and Lang, C. (2015). Sustainable product-service systems for clothing: exploring consumer perceptions of consumption alternatives in Finland. J. Cleaner Prod. 97, 30-39. doi: 10.1016/j.jclepro.2014.01.046

Barnes, L., and Lea-Greenwood, G. (2006). Fast fashioning the supply chain: Shaping the research agenda. J. Fashion Market. Manage. 10, 259-271. doi: $10.1108 / 13612020610679259$

Björkdahl, J. (2009). Technology cross-fertilization and the business model: the case of integrating ICTs in mechanical engineering products. Res. Policy 39 No. 9, 1468-1477. doi: 10.1016/j.respol.2009.07.006

Bocken, N. M. P., Miller, K., Weissbrod, I., Holgado, M., and Evans, S. (2017). Business model experimentation for circularity: driving sustainability in a large international clothing retailer. Econ. Policy Energy Environ. 2017, 85-122. doi: 10.3280/EFE2017-001006

Bocken, N. M. P., Schuit, C. S. C., and Kraaijenhagen, C. (2018). Experimenting with a circular business model: Lessons from eight cases. Environ. Innov. Soc. Trans. 28, 79-95. doi: 10.1016/j.eist.2018.02.001

Bortoloni, R. F., Cortimiglia, M. N., Danilevicz, A. M. F., and Ghezzi, A. (2021). Lean Startup: a comprehensive historical review. Manage. Decis. 59, 1765-1783. doi: 10.1108/MD-07-2017-0663

Bowman, H., Nikou, S., and Reuver, M. (2019). Digitalization, business models, and SMEs: How do business model innovation practices improve performance of digitalizing SMEs? Telecommun. Policy. 43, 101828. doi: 10.1016/j.telpol.2019.101828
The results indicate that the $\mathrm{CE}$ networks developed through BMI4CEs are based in $\mathrm{B} 2 \mathrm{~B}$ or B2B2C. It is emphasized that the study of CE networks is still little explored in the literature, possibly because CE is still little developed in practice (Braun et al., 2018; Geng et al., 2019). Further research can be made to identify and analyze the formation of CE networks (involving startups and incumbent firms), specifically through BMI4CEs based in $\mathrm{B} 2 \mathrm{~B}$ and $\mathrm{B} 2 \mathrm{~B} 2 \mathrm{C}$ as potential drivers of these strategic network's development.

\section{DATA AVAILABILITY STATEMENT}

The raw data supporting the conclusions of this article will be made available by the authors, without undue reservation.

\section{AUTHOR CONTRIBUTIONS}

$\mathrm{CO}, \mathrm{LN}$, and $\mathrm{AZ}$, contributed to the conception and design of the study. CO and LN performed the data collection, data analysis, and wrote sections of the manuscript. All authors contributed to manuscript revision, read, and approved the submitted version.

\section{ACKNOWLEDGMENTS}

We would like to thank Athos Ribeiro, and Natália Rohenkohl do Canto for their input on an earlier draft of this manuscript.

Braun, A. T., Kleine-Moellhoff, P., Reichenberger, V., and Seiter, S. (2018). Case study analysing potentials to improve material efficiency in manufacturing supply chains, considering circular economy aspects. Sustainability 10, 1-12. doi: $10.3390 /$ su10030880

Bruning, C., Godri, L., and Takahashi, A. R. W. (2018). Triangulação em estudos de caso: incidência, apropriações e mal-entendidos em pesquisas da área de administração. Administração 19, 277-307. doi: 10.13058/raep.2018.v19n2.889

Camacho-Otero, J., Boks, C., and Pettersen, I. N. (2018). Consumption in the circular economy: a literature review. Sustainability. 10, 2758. doi: $10.3390 /$ su10082758

Carrillo-Hermosilla, J., Del Río, P., and Könnöl,ä, T. (2010). Diversity of eco-innovations: reflections from selected case studies. J Cleaner Prod. 18, 1073-1083. doi: 10.1016/j.jclepro.2010.02.014

Centobelli, P., Cerchione, R., Chiaroni, D., Del Vecchio, P., and Urbinati, A. (2020). Designing business models in circular economy: a systematic literature review and research agenda. Bus. Strateg. Environ. 29, 1734-1749. doi: 10.1002/bse.2466

Chesbrough, H. (2010). Business model innovation: opportunities and barriers. Long Range Plan. 43, 354-363. doi: 10.1016/j.lrp.2009.07.010

Colucci, M., and Vecchi, A. (2020). Close the loop : Evidence on the implementation of the circular economy from the Italian fashion industry. Bus. Strat. Environ. 30, 856-873. doi: 10.1002/bse.2658

Copenhagen Fashion Summit (2019a). 10 years of rewriting fashion. Available online at: https://copenhagenfashionsummit.com/about\#team

Copenhagen Fashion Summit (2019b). Future Lab: 10 ideas that can change fashion. Available online at: https://copenhagenfashionsummit.com/ innovationforum/\#futurelab

Creswell, J. W. (2010). Projeto de Pesquisa: Métodos Qualitativo, Quantitativo e Misto. (3. ed.). Porto Alegre: Artmed.

de Brito, M. P., Carbone, V., and Blanquart, C. M. (2008). Towards a sustainable fashion retail supply chain in Europe: organisation and performance. Int. J. Prod. Econ. 114, 534-553. doi: 10.1016/j.ijpe.2007.06.012 
de Jesus, A., Antunes, P., Santos, R., and Mendonça, S. (2019). Eco-innovation pathways to a circular economy: envisioning priorities through a Delphi approach. J Cleaner Prod. 228, 1494-1513. doi: 10.1016/j.jclepro.2019.04.049

Demirel, P., Li, Q. C., Rentocchini, F., and Tamvada, J. P. (2017). Born to be green: new insights into the economics and management of green entrepreneurship. Small Bus. Econ. 52, 759-771. doi: 10.1007/s11187-017-9933-z

Diaz Lopez, F. J., Bastein, T., and Tukker, A. (2019). Business model innovation for resource-efficiency, circularity and cleaner production: what 143 cases tell us. Ecol. Econ. 155, 20-35. doi: 10.1016/j.ecolecon.2018.03.009

Dullius, A. C., and Schaeffer, P. R. (2016). Innovation capabilities in startups: contributions towards growth. Rev. Alcance. 23, 34-50. doi: 10.14210/alcance.v23n1.p034-050

Eisenhardt, K. M., and Graebner, M. E. (2007). Theory building from cases: opportunities and challenges. Acad. Manage. J. 50, 25-32. doi: 10.5465/amj.2007.24160888

Elkington, J. (1998). Cannibals with Forks: The Triple Bottom Line of 21st Century Business, New Society. Publishers, Stoney Creek, CT. doi: $10.1002 /$ tqem.3310080106

Ellen MacArthur Foundation (2013). Towards the Circular Economy: Economic and Business Rationale for an Accelerated Transition (01-97). Available online at: https://www.ellenmacarthurfoundation.org/assets/downloads/publications/ Ellen-MacArthur-Foundation-Towards-the-Circular-Economy-vol.1.pdf

Ellen MacArthur Foundation (2021). What is the Circular Economy? Available online at: https://www.ellenmacarthurfoundation.org/circular-economy/whatis-the-circular-economy

Esposito, M., Tse, T., and Soufani, K. (2017). Reverse logistics for postal services within a circular economy. Thunderbird Int. Bus. Rev. 60 No. 4, 741-745. doi: 10.1002/tie.21904

Fernandes, S., da, C., Pigosso, D. C. A., Mcaloone, T. C., and Rozenfeld, H. (2020). Towards product-service system oriented to circular economy : a systematic review of value proposition design approaches. J Cleaner Prod. 257, 120507. doi: $10.1016 /$ j.jclepro.2020.120507

Fjeldstad, Ø. D., and Snow, C. C. (2018). Business models and organization design. Long Range Plan. 51, 31-39. doi: 10.1016/j.lrp.2017.07.008

Foss, N. J., and Saebi, T. (2017). Fifteen years of research on business model innovation: how far have we come, and where should we go? J Manage. 43, 200-227. doi: 10.1177/0149206316675927

Freytag, R. (2019). On a growth track with startups: how established companies can pursue innovation. Strat. Leaders. 47, 26-33. doi: 10.1108/SL-05-2019-0070

Galleli, B., Sutter, M. B., and MacLennan, M. L. F. (2015). Perspectives of Sustainability in Brazilian Fashion for the International Market. Rev. Gestão Soc. Ambient. 9, 45-62. doi: 10.24857/rgsa.v9i3.1094

Geissdoerfer, M., Morioka, S. N., de Carvalho, M. M., and Evans, S. (2018a). Business models and supply chains for the circular economy. J. Cleaner Prod. 190, 712-721. doi: 10.1016/j.jclepro.2018.04.159

Geissdoerfer, M., Savaget, P., Bocken, N. M. P., and Jan, E. (2017). The Circular Economy: a new sustainability paradigm? J. Cleaner Prod. 143, 757-768. doi: 10.1016/j.jclepro.2016.12.048

Geissdoerfer, M., Vladimirova, D., Fossen, K., Van and Evans, S. (2018b). Product, service, and business model innovation: a discussion. Procedia Manuf. 21, 165-172. doi: 10.1016/j.promfg.2018.02.107

Geng, Y., Sarkis, J., and Bleischwitz, R. (2019). How to globalize the circular economy. Nature 565, 153-155. doi: 10.1038/d41586-019-00017-z

Ghisellini, P., Cialani, C., and Ulgiati, S. (2016). A review on circular economy: the expected transition to a balanced interplay of environmental and economic systems. J Cleaner Prod. 114, 11-32. doi: 10.1016/j.jclepro.2015.09.007

Henry, M., Bauwens, T., Hekkert, M., and Kirchherr, J. (2020). A typology of circular startups: Analysis of 128 circular business models. J. Cleaner Prod. 245, 118528. doi: 10.1016/j.jclepro.2019.118528

Hofmann, F. (2019). Circular business models: Business approach as driver or obstructer of sustainability transitions? J. Cleaner Prod. 224, 361-374. doi: 10.1016/j.jclepro.2019.03.115

Jaeger, B., and Upadhyay, A. (2020). Understanding barriers to circular economy: cases from the manufacturing industry. J. Enterpr. Inf. Manage. 33, 729-745. doi: 10.1108/JEIM-02-2019-0047

Kirchherr, J., Reike, D., and Hekkert, M. (2017). Conceptualizing the circular economy: an analysis of 114 definitions. Resour. Conserv. Recycl. 127, 221-232. doi: 10.1016/j.resconrec.2017.09.005
Kohler, T. (2016). Corporate accelerators: Building bridges between corporations and startups. Bus. Horizon. 59, 347-357. doi: 10.1016/j.bushor.2016.01.008

Korhonen, J., Honkasalo, A., and Seppäl,ä, J. (2018). Circular economy: the concept and its limitations. Ecol. Econ. 143, 37-46. doi: 10.1016/j.ecolecon.2017.06.041

Kozlowski, A., Searcy, C., and Bardeckir, M. (2015). Corporate sustainability reporting in the apparel industry. Int. J. Prod. Perform. Manage. 64, 377-397. doi: 10.1108/IJPPM-10-2014-0152

Lewandowski, M. (2016). Designing the business models for circular economy-towards the conceptual framework. Sustainability 8, 1-28. doi: 10.3390/su8010043

Linder, M., and Williander, M. (2017). Circular business model innovation: inherent uncertainties. Bus. Strat. Environ. 26, 182-196. doi: 10.1002/bse.1906

Lüdeke-Freund, F., Gold, S., and Bocken, N. M. P. (2019). A review and typology of circular economy business model patterns. J. Ind. Ecol. 23, 36-61. doi: $10.1111 /$ jiec. 12763

Lueg, R., Pedersen, M. M., and Clemmensen, S. N. (2013). The role of corporate sustainability in a low-cost business model - a case study in the scandinavian fashion industry. Bus. Strat. Environ. 24, 344-359. doi: 10.1002/bse.1825

Manninen, K., Koskela, S., Antikainen, R., Bocken, N., Dahlbo, H., and Aminoff, A. (2018). Do circular economy business models capture intended environmental value propositions? J. Clean. Prod. 171, 413-422. doi: 10.1016/j.jclepro.2017.10.003

Maxwell, D., and van der Vorst, R. (2003). Developing sustainable products and services. J. Clean Prod. 11, 883-895. doi: 10.1016/S0959-6526(02)00164-6

McGrath, R. G. (2010). Business models: a discovery driven approach. Long Range Planning. 43, 247-261. doi: 10.1016/j.lrp.2009.07.005

Merli, R., Preziosi, M., and Acampora, A. (2018). How do scholars approach the circular economy? A systematic literature review. J. Cleaner Prod. 178, 703-722. doi: 10.1016/j.jclepro.2017.12.112

Mrkajic, B., Murtinu, S., and Scalera, V. G. (2019). Is green the new gold? Venture capital and green entrepreneurship. Small Bus. Econ. 52, 929-950, doi: 10.1007/s11187-017-9943-x

Murray, A., Skene, K., and Haynes, K. (2017). The circular economy: an interdisciplinary exploration of the concept and application in a global context. J. Bus. Ethic. 140, 369-380. doi: 10.1007/s10551-015-2693-2

Nascimento, L. S., and Steinbruch, F. K. (2019). The interviews were transcribed but how? Reflections on management research. RAUSP Manage. J. 54, 413-429. doi: 10.1108/RAUSP-05-2019-0092

Niinimäki, K., Peters, G., Dahlbo, H., Perry, P., Rissanen, T., and Gwilt, A. (2020). The environmental price of fast fashion. Nat. Rev. Earth Environ. 1, 189-200. doi: 10.1038/s43017-020-0039-9

Nußholz, J. L. K. (2017). Circular business models: defining a concept and framing an emerging research field. Sustainability 9, 14-17. doi: 10.3390/su9101810

Ostermann, C. M., da Silva Nascimento, L., Steinbruch, F. K., and Callegarode-Menezes, D. (2021). Drivers to implement the circular economy in bornsustainable business models: a case study in the fashion industry. Rev. Gestão. 28, 223-240. doi: 10.1108/REGE-03-2020-0017

Osterwalder, A., and Pigneur, Y. (2010). Business model generation: a handbook for visionaries, game changers, and challengers, John Wiley and Son. Available online at: https://www.wiley.com/en-us/Business\$+\$Model\$+\$Generation $\% 3 \mathrm{~A} \$+\$ \mathrm{~A} \$+\$$ Handbook $\$+\$$ for $\$+\$$ Visionaries $\% 2 \mathrm{C} \$+\$$ Game $\$+\$ C h a n g e r s$ $\% 2 \mathrm{C} \$+\$$ and $\$+\$$ Challengers-p-9781118656402

Pagoropoulos, A., Pigosso, D. C. A., and Mcaloone, T. C. (2017). The emergent role of digital technologies in the Circular Economy: a review. Procedia CIRP 64, 19-24. doi: 10.1016/j.procir.2017.02.047

Pedersen, E. R. G., Gwozdz, W., and Hvass, K. K. (2018). Exploring the relationship between business model innovation, corporate sustainability, and organisational values within the fashion industry. J. Bus. Ethic. 149, 267-284. doi: 10.1007/s10551-016-3044-7

Pieroni, M. P. P., McAloone, T. C., and Pigosso, D. C. A. (2019). Business model innovation for circular economy and sustainability: A review of approaches. J. Cleaner Prod. 215, 198-216. doi: 10.1016/j.jclepro.2019.01.036

Pisoni, A., and Onetti, A. (2018). When startups exit: comparing strategies in Europe and the USA. J. Bus. Strat. 39, 26-33. doi: 10.1108/JBS-02-2017-0022

Prieto-Sandoval, V., Jaca, C., and Ormazabal, M. (2018). Towards a consensus on the circular economy. J. Cleaner Prod. 179, 605-615. doi: 10.1016/j.jclepro.2017.12.224 
Ranta, V., Aarikka-Stenroos, L., and Väisänen, J. M. (2021). Digital technologies catalyzing business model innovation for circular economy-Multiple case study. Resour. Conserv. Recycl. 164, 105155. doi: 10.1016/j.resconrec.2020.105155

Rosa, P., Sassanelli, C., Urbinati, A., Chiaroni, D., and Terzi, S. (2020). Assessing relations between Circular Economy and Industry 4.0: a systematic literature review. Int. J. Prod. Res. 58, 1662-1687. doi: 10.1080/00207543.2019.16 80896

Saberi, S., Kouhizadeh, M., Sarkis, J., and Shen, L. (2019). Blockchain technology and its relationships to sustainable supply chain management. Int. J. Prod. Res. 57, 2117-2135. doi: 10.1080/00207543.2018.1533261

Schiavi, G. S., Behr, A., and Marcolin, C. B. (2019). Conceptualizing and qualifying disruptive business models. RAUSP Manage. J. 54, 269-286. doi: 10.1108/RAUSP-09-2018-0075

Shafer, S. M., Smith, H. J., and Linder, J. C. (2005). The power of business models. Bus. Horizon. 48, 199-207. doi: 10.1016/j.bushor.2004.10.014

Sigglekow, N. J. (2007). Persuasion with case studies. Acad. Manage. J. 50, 20-24, doi: 10.5465/amj.2007.24160882

Spender, J. C., Corvello, V., Grimaldi, M., and Rippa, P. (2017). Startups and open innovation: a review of the literature. Eur. J. Innov. Manage. 20, 4-30. doi: 10.1108/EJIM-12-2015-0131

Talay, C., Oxborrow, L., and Brindley, C. (2018). How small suppliers deal with the buyer power in asymmetric relationships within the sustainable fashion supply chain. J. Bus. Res. 117, 604-614. doi: 10.1016/j.jbusres.2018.08.034

Teece, D. J. (2010). Business models, business strategy and innovation. Long Range Planning. 43, 172-194. doi: 10.1016/j.lrp.2009.07.003

Todeschini, B. V., Cortimiglia, M. N., Callegaro-de-Menezes, D., and Ghezzi, A. (2017). Innovative and sustainable business models in the fashion industry: entrepreneurial drivers, opportunities, and challenges. Bus. Horizon. 60, 759-770. doi: 10.1016/j.bushor.2017.07.003

Tukker, A. (2015). Product services for a resource-efficient and circular economy e a review. J. Cleaner Prod. 97, 76-91. doi: 10.1016/j.jclepro.2013.11.049

Tura, N., Hanski, J., Ahola, T., Stahle, M., and Piiparinen, S. (2019). Unlocking circular business: a framework of barriers and drivers. J. Cleaner Prod. 212, 90-98, jclepro.2018.11.202 doi: 10.1016/j.jclepro.2018.11.202

Upadhyay, A., Akter, S., Adams, L., Kumar, V., and Varma, N. (2019). Investigating "circular business models" in the manufacturing and service sectors. J. Manuf. Technol. Manage. 30, 590-606. doi: 10.1108/JMTM-02-20 18-0063

Upadhyay, A., Ayodele, J. O., Kumar, A., and Garza-Reyes, J. A. (2021a). A review of challenges and opportunities of blockchain adoption for operational excellence in the UK automotive industry. J. Global Oper. Strat. Sourc. 14, 7-60. doi: 10.1108/JGOSS-05-2020-0024

Upadhyay, A., Kumar, A., and Akter, S. (2021b). An analysis of UK retailers' initiatives towards circular economy transition and policy-driven directions. Clean Technol. Environ. Policy. 0123456789. doi: 10.1007/s10098-020-02004-9

Urbinati, A., Chiaroni, D., and Chiesa, V. (2017). Towards a new taxonomy of circular economy business models. J. Cleaner Prod. 168, 487-498. doi: 10.1016/j.jclepro.2017.09.047

Urbinati, A., Chiaroni, D., Chiesa, V., and Frattini, F. (2019). The role of business model design in the diffusion of innovations: an analysis of a sample of unicorn-tech companies. Int. J. Innov. Technol. Manage. 16, 1950011. doi: 10.1142/S0219877019500111

Urbinati, A., Rosa, P., Sassanelli, C., Chiaroni, D., and Terzi, S. (2020). Circular business models in the European manufacturing industry: A multiple case study analysis. J. Cleaner Prod. 274, 122964. doi: 10.1016/j.jclepro.2020.122964

Weiblen, T., and Chesbrough, H. W. (2015). Engaging with startups to enhance corporate innovation. California Managem. Rev. 57, 66-90. doi: $10.1525 / \mathrm{cmr} .2015 .57 .2 .66$

White, K., Habib, R., and Hardisty, D. J. (2019). How to SHIFT consumer behaviors to be more sustainable : a literature review and guiding framework. J. Market. 83, 22-49. doi: 10.1177/0022242919825649

Yin, R. K. (1994). Case Study Research: Design and Methods. Sage, London, UK.

Conflict of Interest: The authors declare that the research was conducted in the absence of any commercial or financial relationships that could be construed as a potential conflict of interest.

Publisher's Note: All claims expressed in this article are solely those of the authors and do not necessarily represent those of their affiliated organizations, or those of the publisher, the editors and the reviewers. Any product that may be evaluated in this article, or claim that may be made by its manufacturer, is not guaranteed or endorsed by the publisher.

Copyright (c) 2021 Ostermann, Nascimento and Zen. This is an open-access article distributed under the terms of the Creative Commons Attribution License (CC BY). The use, distribution or reproduction in other forums is permitted, provided the original author(s) and the copyright owner(s) are credited and that the original publication in this journal is cited, in accordance with accepted academic practice. No use, distribution or reproduction is permitted which does not comply with these terms. 